\title{
Correlation of Biochemical Markers with Histopathological Findings in Experimental Strangulated Hernia
}

\author{
Deneysel Boğulmuş Fıtık Modelinde Biyokimyasal ve Histopatolojik Bulguların Karşılaştırılması
}

\author{
Yusuf PEKER, ${ }^{1}$ Fahrettin YILDIZ, ${ }^{2}$ Nazif ZEYBEK, ${ }^{1}$ Türker ÇETIN, ${ }^{3}$ \\ Levent KENAR, ${ }^{4}$ Muhittin SERDAR, ${ }^{5}$ Bülent KURT, ${ }^{6}$ Turgut TUFAN ${ }^{1}$ \\ Departments of ${ }^{1}$ General Surgery, ${ }^{3}$ Hematology, ${ }^{4}$ Nuclear Biological and Chemical, \\ ${ }^{5}$ Clinical Biochemistry, ${ }^{6}$ Pathology, Gülhane Military Medical School, Ankara; \\ Department of ${ }^{2}$ General Surgery, Medical Faculty of Harran University, Şanluurfa
}

Submitted / Başvuru tarihi: 01.12.2008 Accepted / Kabul tarihi: 02.02.2009

\begin{abstract}
Objectives: This study was planned to evaluate whether possible changes in the hematological parameters and the biochemical markers can be used to detect obstruction-induced (strangulated) intestinal ischemia.
\end{abstract}

Materials and Methods: Forty rats divided into five groups underwent the following procedures: Group 1 rats were treated with only laparotomy (sham-operated controls). To the strangulated hernia groups surgical induction of strangulated intestinal obstruction was performed. Tissue and blood samples were taken at 30 minutes (group 2), 2nd hour (group 3), 4th hour (group 4) and 6th hour (group 5) respectively, and then LDH, CPK, ALP, AST, ALT, D-dimer levels and blood cells counts were measured and histopathological examination was done.

Results: Focal mucosal necrosis accompanied was confirmed by histological findings in the strangulated intestinal ischemia group after second hour. Serum D-dimer, ALT, ALP, CPK levels and neutrophil count became elevated at second hour, which was statistically significant.

Conclusion: In patients with hernia, after reduction of the intestinal hernia, raised levels of serum D-dimer, ALT, ALP, CPK levels and neutrophil count may indicate the presence of a bowel ischemia. However, more comprehensive clinical studies are required to evaluate the potential survival benefit by using the laboratory tests as a marker and/or a useful diagnostic tool of the need for laparotomy. Key words: Strangulated hernia; D-dimer; ALT; AST; CPK.
Amaç: Bu çalışmada obstrüksiyonun neden olduğu intestinal iskeminin tespiti için, hematolojik parametreler ve biyokimyasal göstergelerdeki değişikliklerin kullanılıp kullanılamayacağı araştıııldı.

Gereçler ve Yöntemler: Beş gruba bölünen 40 adet sıçana şu yöntemler uygulandı: Grup 1'deki sıçanlara sadece laparotomi yapıldı, diğer strangüle herni gruplarına ise cerrahi olarak strangüle intestinal obstrüksiyon oluşturuldu. Doku ve kan örnekleri sırasıyla 30. dakikada (grup 2), 2. saatte (grup 3), 4. saatte (grup 4) ve 6. saatte (grup 5) alındı ve daha sonra LDH, CPK, ALP, AST, ALT, D-dimer seviyeleri, tam kan sayımı ölçüldü ve histopatolojik inceleme yapıldı.

Bulgular: Eşlik eden fokal mukozal nekroz histolojik bulgularla strangüle intestinal iskemi grubunda 2. saatte gözlendi. Serum D-dimer, ALT, ALP, CPK seviyeleri ve nötrofil sayımı 2. saatte arttı ve istatistiksel olarak anlamlıydı.

Sonuç: Fıtık hastalarında redüksiyon sonrasında artmış serum D-dimer, ALT, ALP, CPK seviyelerive nötrofil sayımı barsak iskemisinin bir göstergesi olabilir. Bununla birlikte laparatomi gereksiniminin göstergesi olabilecek testlerin potansiyel faydalarının değerlendirilmesi için daha geniş prospektif klinik çalışmalara intiyaç vardır.

Anahtar sözcükler: Boğulmuş fıtık; D-dimer; ALT; AST; CPK.

Correspondence (illetişim adresi): Dr. Fahrettin Yıldız. Harran Üniversitesi Tıp Fakültesi Genel Cerrahi Anabilim Dalı, 63300 Şanlıurfa.

Tel: 0414 - 3183138 Fax (Faks): 0414 - 3183192 e-mail (e-posta): fahrettinyildiz@hotmail.com

(c) Trakya Üniversitesi Tıp Fakültesi Dergisi. Ekin Tıbbi Yayıncılık tarafından basılıışır. Her hakkı sakııdır.

(c) Medical Journal of Trakya University. Published by Ekin Medical Publishing. All rights reserved. 
Inguinal hernia operations are the most common procedure performed by the general surgeons. The most common complication of this hernia is the incarceration of bowel leading to obstruction, reduction in blood supply and ischemic bowel. This occurs especially in very young babies. If missed, it leads to perforation, peritonitis, septicemia and death. So that, acute intestinal ischemia due to strangulated hernia or other causes have considerable morbidity and mortality rates. The high mortality and morbidity rates are mainly due to delay in diagnosis. Whatever the cause, the result of intestinal ischemia is injury ranging from completely reversible functional alterations to transmural hemorrhagic necrosis of portions or all of the bowel by the time. An early diagnosis in bowel ischemia prevents the necrosis, while the elimination of the obstruction relieves the patient free of the risk for peritonitis that is triggered by the perforation of the intestinal wall. ${ }^{[1-3]}$

The key is not to delay laparotomy unnecessarily. So that it is of great importance to find a specific and rapidly elevating marker. The search in this field should be directed to a simple, accurate, objective, and costeffective test for diagnosis before changes resulted in irreversible damage in the intestinal wall. ${ }^{[4]}$

The interventional radiologist can diagnose intestinal ischemia effectively with angiography which is still gold standard for the diagnosis of bowel infarction. However, contraindications to arteriography include hypotension or hypovolemia because of potentially increasing vasoconstriction and reducing specificity of findings. Contrast-induced nephrotoxicity should be considered. [5,6] Overall rate of major complications of mesenteric angiography which may include external iliac artery dissection or deep venous thrombosis is $1.9-2.9 \% .^{[7]}$

To enhance the early diagnosis of bowel ischemia and judgment of its severity, it may be helpful to detect the unusual existence or alterations in biomarkers in the body fluid. Yet, methods to diagnose are not useful enough for a successful diagnosis. ${ }^{[8]}$

D-dimer is a plasmin-mediated fibrin degradation product. In recent studies, it has been suggested that serum D-dimer levels might be used for early diagnosis of intestinal infarction. ${ }^{[4,9]}$

The aim of this study was to assess the relevance of some serum biochemical parameters such as $\mathrm{LDH}$, CPK, ALP, AST, ALT levels and analysis of whole blood count as a possible reliable marker for the diagnosis of intestinal ischemia.

\section{MATERIALS AND METHODS}

Forty male wistar albino rats weighing between 220 and $280 \mathrm{~g}$ were included into the study. The rats received free access to normal food and water before the experiment. Rats were divided into five groups each including eight rats. No surgical intervention was applied to group I (control) rats. For other four study groups, intestinal strangulation was employed for 30 minutes, 2, 4 and 6 hours, respectively through group 2 to group 5. After sacrification, blood and intestinal tissue samples were taken and blood CPK, ALP, ALT, AST, LDH, D-dimer, hematocrit levels, lymphocyte, neutrophil, platelets and leukocyte counts were also detected.

The experimental protocol was designed according to the Principles of Laboratory Animal Care and ethical standards for animal use and approved by the local ethical committee for animal use of experimental purposes.

\section{Induction of Ileal Loop Strangulation}

After an overnight fast, anesthesia was administered by $10 \mathrm{mg} / \mathrm{kg}$ ketamine hydrochloride (Ketalar®, Eczacıbaş1, İstanbul) intraperitoneally. After a $2 \mathrm{~cm}$ midline skin incision, then $5 \mathrm{~cm}$ long ileal loop was pulled trough the hole constituted on the fascia into subcutaneous area and subjected to strangulation. The hole on the fascia was narrowed up to approximately $0.5 \mathrm{~cm}$ by prolene suture for standardization and insurance of strangulation intestinal ischemia (Fig. 1). All rats were then resuscitated with 10 $\mathrm{ml}$ of normal saline solution into the peritoneum. No antibiotics and analgesics were used in the study.

\section{Laboratory Analysis}

Blood samples were collected by cardiac puncture into tubes containing $0.123 \mathrm{~mol} / \mathrm{L}$ sodium citrate. Plasma was separated by centrifugation at $3000 \mathrm{~g}$ for $10 \mathrm{~min}$ and stored at $-70^{\circ} \mathrm{C}$ until assay. A latex agglutination test (D-di Test $\AA$, Diagnostica Stago, France) was used for D-dimer measurements. Values of $<0.5 \mu \mathrm{g} / \mathrm{ml}$ were considered normal, since the D-di Test reacts with the levels of $>0.5 \mu \mathrm{g} / \mathrm{ml}$. Leucocytes, neutrophils, platelets and lymphocytes were measured on ABX-PENTRA 120 DX® Hematology Analyzer (ABX Diagnostics, France). Biochemistry testing, including AST, ALT, LDH, ALP, CPK and D-Dimer was measured by UV-kinetic method with Olympus AU 2700® autoanalyzer (Olympus Diagnostics GmbH, Hamburg, Germany).

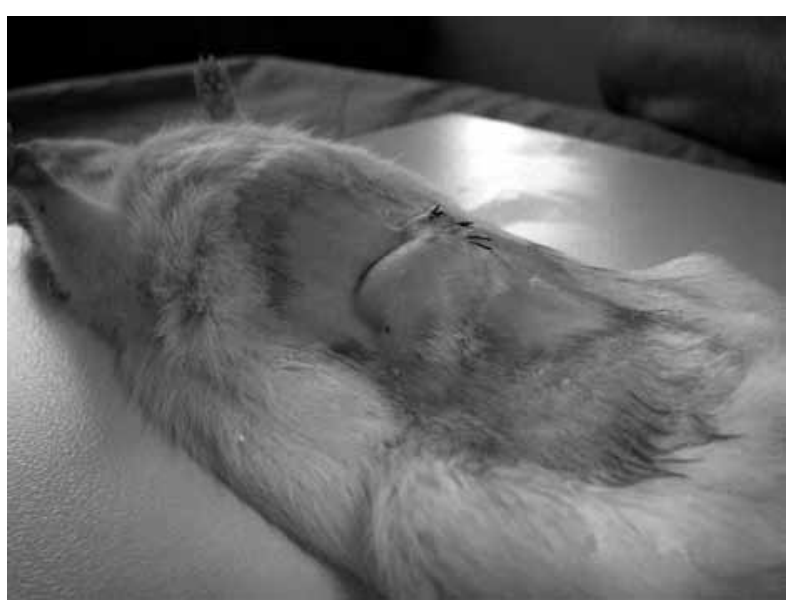

Fig. 1. The appearance of subjected strangulated hernia in a rat. 


\section{Histopathologic Examination}

Tissue samples from ischemic intestinal segment were fixed in buffered formaline for 24 hours. After routine pathologic proceeding, paraffin blocks were obtained and $5 \mu \mathrm{m}$ thickness tissue slides were stained with hematoxylin and eosin. Tissue necrosis in stained slides were examined with light microscope (Nikon ${ }^{\circledR}$, Tokyo, Japan). Histopathological results were graded as from grade 1 to grade 4 representing normal tissue, partial mucosal necrosis, mucosal hemorrhagic infarction and transmural hemorrhagic infarction, respectively.

\section{Statistical Analysis}

All data were assessed using a SPSS 11.5 for Windows for statistical analysis (SPSS $®$ for Windows, 11.5, SPSS Inc., USA). Parametric statistical methods were used to analyze the data. Results were presented as mean \pm SD . Following One-Way ANOVA test, Tukey and LSD posthoc tests were used. Two-sided $p$ value of 0.05 or less was considered to be significant.

\section{RESULTS}

The samples were evaluated blindly by a pathologist in a light microscope. The histopathological evaluation of the small intestine samples obtained from all members of groups. In group 1 there were no pathological findings. In group 2 dilatation were only seen in mucosal and submucosal vessels and no tissue necrosis was found (Fig. 3a). In Group 3, there were focal mucosal necrosis accompanied by dilated mucosal and submucosal vessels. However, in all segments, submucosa and muscularis propria were found intact (Fig. 3b). In 4th, 5th and 6th Groups, major histopathologic findings were transmural tissue necrosis, mucosal necrosis in wide areas, and intact mucosa was very scant (Fig. 3c).

Beside these, there was about 2 times increase in the levels of CPK levels of group 3 compared to group $2(p=0.033)$. The increase in ALT levels were highly significant at 2nd hour as compared to control group's ( $<<0.001)$. Also, ALP, neutrophil and D-dimer levels of groups (group 2, 3, 4, 5 and 6) became increased and a statistical significance was found at 2 nd hour in a relationship with the histopathological findings $(\mathrm{p}<0.001$,
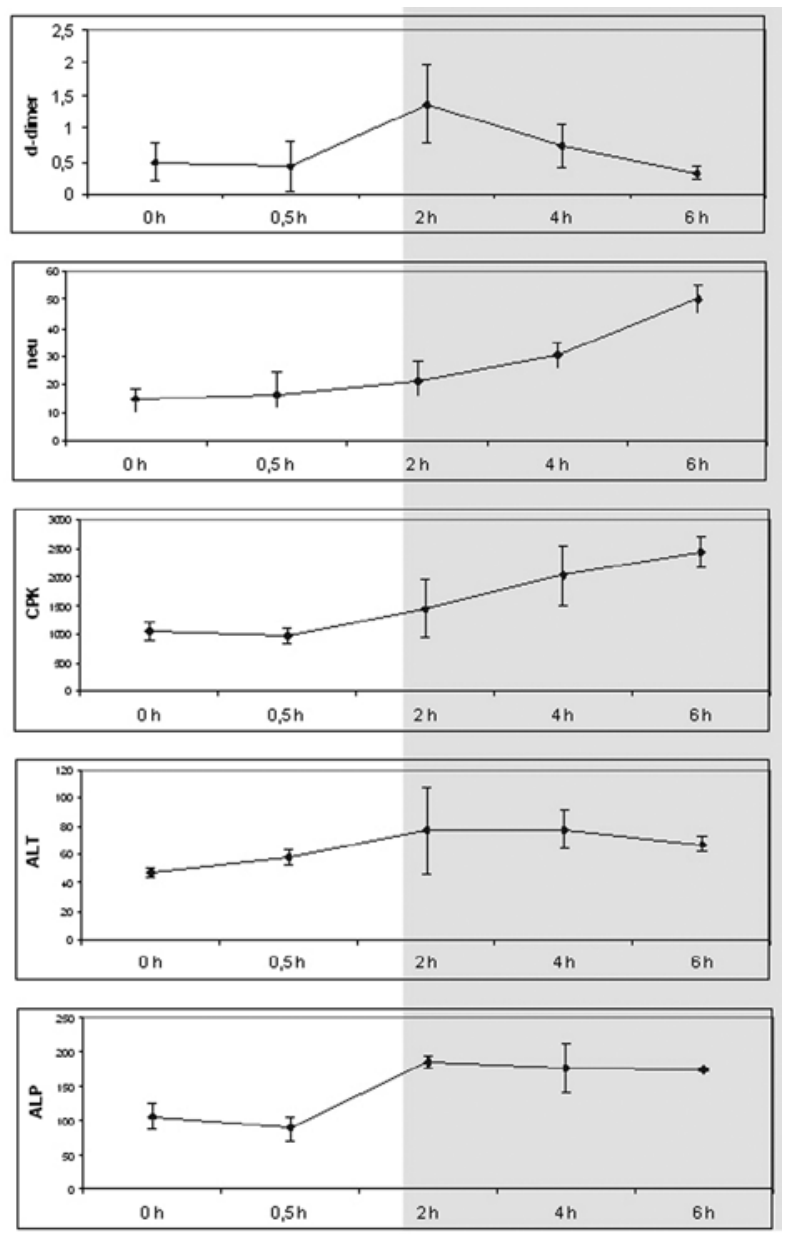

Fig. 2. Line graphics illustrating the increase in serum parameters by the time.

$\mathrm{p}=0.034, \mathrm{p}<0.001$, respectively). In spite of the fact that the other parameters increased the results were not statistically significant (Table 1) (Fig. 2).

\section{DISCUSSION}

In acute intestinal ischemia due to strangulated hernia or any other reason, mortality and morbidity rates are still high. It is in consequence of delay in diagnosis due to lack of a simple, accurate and objective test indicating
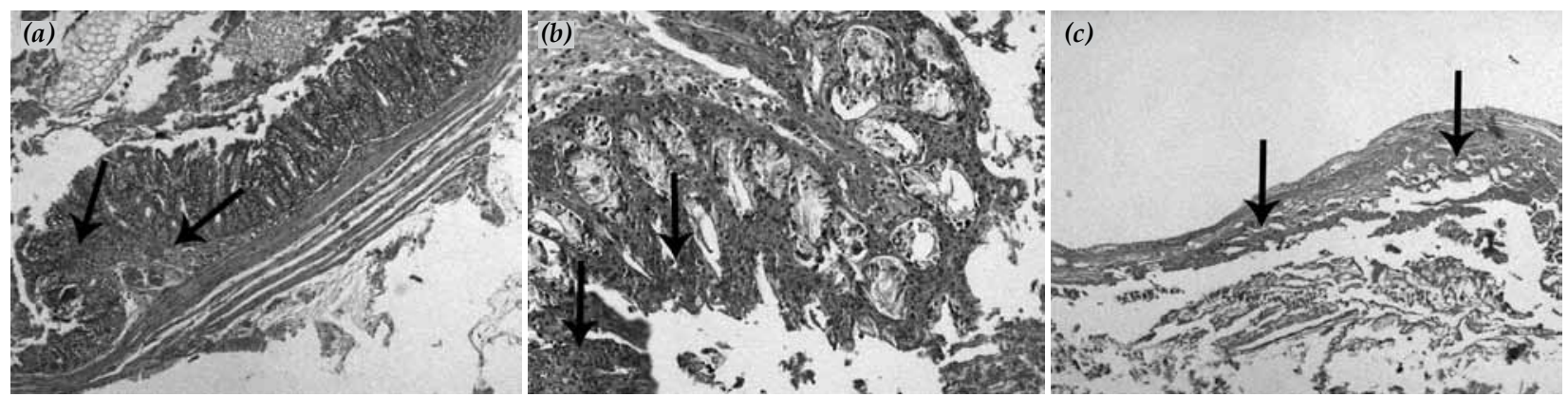

Fig. 3. (a) Vascular dilatations and necrosis in submucosal region are illustrated (HE $x$ 50). (b) Focal mucosal necrosis and inflammatory infiltrations of PMNL into the lamina propria are seen (HE $x$ 100). (c) Transmural necrosis (HE $x$ 50). 
Table 1: The mean levels of studied parameters related to time

\begin{tabular}{lccccc}
\hline & Control & $30 \mathrm{~min}$ & $2 \mathrm{~h}$ & $4 \mathrm{~h}$ & $6 \mathrm{~h}$ \\
\hline $\begin{array}{l}\mathrm{D}-\text { dimer } \\
\mu \mathrm{g} / \mathrm{ml}\end{array}$ & 0.495 & 0.423 & 1.368 & 0.730 & 0.220 \\
$\begin{array}{l}\mathrm{Neu} \\
103 / \mu \mathrm{L}\end{array}$ & 15.175 & 16.425 & 21.438 & 30.550 & 50.175 \\
$\mathrm{ALT}$ & & & & & \\
$\mathrm{U} / \mathrm{L}$ & 47.375 & 57.750 & 77.500 & 78 & 67.500 \\
$\mathrm{AST}$ & & & & & \\
$\mathrm{U} / \mathrm{L}$ & 144.250 & 130 & 139.500 & 224 & 326 \\
$\begin{array}{l}\mathrm{Htc} \\
\%\end{array}$ & 40.175 & 44.825 & 46.963 & 48.800 & 45.300 \\
$\mathrm{LDH}$ & & & & & \\
$\mathrm{U} / \mathrm{L}$ & 628 & 599.750 & 578.500 & 1067 & 1549.500 \\
$\mathrm{Lym}$ & & & & & \\
$\begin{array}{l}103 / \mu \mathrm{L} \\
\mathrm{ALP}\end{array}$ & 82.300 & 79.525 & 77.813 & 62.400 & 44.275 \\
$\mathrm{U} / \mathrm{L}$ & 107 & 89 & 186.125 & 177.750 & 175 \\
$\mathrm{CPK}$ & & & & & \\
$\mathrm{U} / \mathrm{L}$ & 1047.250 & 964.250 & 1448.375 & 2019.75 & 2444 \\
$\mathrm{Plt}$ & & & & & \\
$\begin{array}{l}103 / \mu \mathrm{L} \\
\mathrm{WBC}\end{array}$ & 522 & 586.750 & 434.625 & 569 & 573 \\
$103 / \mu \mathrm{L}$ & 4875 & 3975 & 5362.500 & 4737.500 & 6175 \\
\hline
\end{tabular}

intestinal necrosis. ${ }^{[9]}$ When the degree of the intestinal injury is estimated, it can be decided that whether any additional therapeutic interventions such as resection of necrotic intestine are necessary. Intracellular enzymes can be useful for estimating tissue damage. ${ }^{[10]}$ In addition, D-dimer is supposed to play a role as a potential prognostic marker in many conditions such as pulmonary embolism, coronary arterial diseases. ${ }^{[11,12]}$ Also it is shown that the D-dimer levels and some of hematological parameters are increased in gastrointestinal disorders such as acute upper gastrointestinal hemorrhage and intestinal ischemia reperfusion injury. ${ }^{[13,14]}$

Various studies were designed for definition of parameters that could indicate intestinal necrosis. In this study we inspected the changes in biochemical and hematologic parameters when intestinal ischemia develops by the time and we also demonstrated the relationship between these parameters and the histopathological findings. It discriminates our study from the others. ${ }^{[4,9,15]}$

Lesions of the intestinal submucosa are healed by regeneration. However, when the necrosis reaches the muscular layer in transmural necrosis, more complications develop such as perforation or peritonitis. ${ }^{[1,2]}$ In our experimental study, at 2nd hour, there were mucosal necrosis in all segments, yet submucosa and muscularis propria were found intact. However, beyond the 4th hour, major histopathological findings were transmural tissue necrosis and mucosal necrosis in wide areas, and intact mucosa were very scant. So that, the time beyond the 2 nd hour, it can be assumed that the rate of complications and morbidity will be increased.

In this study, CPK activity, a seromuscular enzyme, started to increase within 2 hours, doubled at 4 th hour and stayed significantly high until six hours $(\mathrm{p}=0.033)$. In the study of Graeber et al., ${ }^{[16]}$ it was discovered that significant elevations in serum total CPK appeared at three hours after injury and reached maximal values at nine hours after injury in the dogs undergoing experimental mesenteric artery infarctions.

The sources of ALP are liver, intestine, placenta and bone. Pathologies involving these tissue and organs cause high levels of ALP. Isoenzymes of ALP can show the source. But, it is not feasible in case of emergency. This is the reason why we prefer to study total ALP levels. In some studies, it has been expressed that the observation of rise in ALP levels might be helpful in diagnosis of mesenteric infarctions. ${ }^{[15,17]}$ In the current study, mean ALP levels increased from control values of $107 \mathrm{IU} / \mathrm{L}$ to $186 \mathrm{IU} / \mathrm{L}$ and it was statistically significant $(\mathrm{p}<0.001)$. And then the levels did not decrease till 6th hour.

In an experimental study in which superior mesenteric arterial occlusion was performed Gumaste et al. ${ }^{[8]}$ found significant increase in ALT levels in portal blood without insignificant increase in heart blood in test animals. Our experimental findings were different from the observations of Gumaste et al. ${ }^{[8]}$ We found that ALT levels were significantly elevated in rats with strangulated hernia after the second hour despite we obtained the blood from heart by puncturing. Our results were consistent with the study of De Toma et al., ${ }^{[15]}$ which was conducted on dogs.

Our results revealed that serum D-dimer levels have increased in a time-dependent fashion till 2 nd hour. The results peaked at 2 nd hour and were statistically significant. It was also consistent with other studies which had implied that the measurements of D-dimer might be used for the early diagnosis of intestinal ischemia. ${ }^{[4,9]}$ However, beyond 2nd hour, the levels started to decrease and also were not meaningful when compared with control group. So, it may not be able to demonstrate the stage and severity of intestinal necrosis.

In case of intestinal obstruction due to intestinal ischemia, the shift of intravascular volume into the bowel wall causes hemoconcentration. ${ }^{[1]}$ In our study, we also observed significant hemoconcentration. But it was not specific for the necrosis. The hemoconcentration started within 30 minutes and endured.

In some studies it was investigated that whether monocyte, neutrophil, and lymphocyte were indicators 
of the immune response and/or whether this response was stimulated by bowel injury. ${ }^{[18,19]}$ In our study, neutrophil levels were significantly elevated at 2 nd hour, when the focal mucosal necrosis accompanied by dilated mucosal and submucosal vessels seen histopathologically. In some studies, it is predicted that there is a doubling of neutrophil count approximately three hours after surgery ${ }^{[20,21]}$ In our study, the doubling time of the neutrophil count was two hours after surgery. Nevertheless lymphocyte levels were decreased with respect to time and it was statistically significant at forth hour.

In the previous studies, the parameters that can indicate the severity of intestinal necrosis were not correlated with histopathological findings. ${ }^{[19,22]}$ In addition to hematological findings and biochemical markers, we evaluated histopathologically the small intestine samples obtained from all members of all groups and compared the results with the laboratory findings. So that the time for the development of irreversible intestinal necrosis is important for the early therapy.

In conclusion, our results suggest that plasma ALT, ALP, CPK, D-dimer levels and neutrophil count are sensitive indicators in the early diagnosis of bowel ischemia demonstrated by histopathological examination and elevations in these parameters may be a diagnostic aid for assessing the necessity of surgical intervention in human. However, a more comprehensive clinical study is required to evaluate the potential survival benefit using the laboratory tests as a marker and/or a useful diagnostic tool for assessing the need for laparotomy.

\section{REFERENCES}

1. Mitsudo S, Brandt LJ. Pathology of intestinal ischemia. Surg Clin North Am 1992;72:43-63.

2. Patel A, Kaleya RN, Sammartano RJ. Pathophysiology of mesenteric ischemia. Surg Clin North Am 1992;72:31-41.

3. Murray MJ, Barbose JJ, Cobb CF. Serum D(-)-lactate levels as a predictor of acute intestinal ischemia in a rat model. J Surg Res 1993;54:507-9.

4. Altinyollar H, Boyabatli M, Berberoğlu U. D-dimer as a marker for early diagnosis of acute mesenteric ischemia. Thromb Res 2006;117:463-7.

5. De Santis L, Bruttocao A, Ciardo L, Militello C, Terranova O. Intestinal infarction in the elderly. Ann Ital Chir 2003;74:2559. [Abstract]

6. Lefkovitz Z, Cappell MS, Lookstein R, Mitty HA, Gerard PS. Radiologic diagnosis and treatment of gastrointestinal hemorrhage and ischemia. Med Clin North Am 2002;86:1357-99.
7. Balduf LM, Langsfeld M, Marek JM, Tullis MJ, Kasirajan K, Matteson B. Complication rates of diagnostic angiography performed by vascular surgeons. Vasc Endovascular Surg 2002;36:439-45.

8. Gumaste UR, Joshi MM, Mourya DT, Barde PV, Shrivastav GK, Ghole VS. Alcohol dehydrogenase: a potential new marker for diagnosis of intestinal ischemia using rat as a model. World J Gastroenterol 2005;11:912-6.

9. Icoz G, Makay O, Sozbilen M, Gurcu B, Caliskan C, Firat $\mathrm{O}$, et al. Is D-dimer a predictor of strangulated intestinal hernia? World J Surg 2006;30:2165-9.

10. Günel E, Cağlayan F, Cağlayan O, Dilsiz A, Duman S, Aktan M. Treatment of intestinal reperfusion injury using antioxidative agents. J Pediatr Surg 1998;33:1536-9.

11. Harrison KA, Haire WD, Pappas AA, Purnell GL, Palmer S, Holdeman KP, et al. Plasma D-dimer: a useful tool for evaluating suspected pulmonary embolus. J Nucl Med 1993;34:896-8.

12. Danesh J, Whincup P, Walker M, Lennon L, Thomson A, Appleby P, et al. Fibrin D-dimer and coronary heart disease: prospective study and meta-analysis. Circulation 2001;103:2323-7.

13. Gutiérrez A, Sánchez-Payá J, Marco P, Pérez-Mateo M. Prognostic value of fibrinolytic tests for hospital outcome in patients with acute upper gastrointestinal hemorrhage. J Clin Gastroenterol 2001;32:315-8.

14. Cağlayan F, Cağlayan O, Gunel E, Elcuman Y, Cakmak M. Intestinal ischemia-reperfusion and plasma enzyme levels. Pediatr Surg Int 2002;18:255-7.

15. De Toma G, Marzano D, Salvatore P, Cerza F, De Cesare E, Giacovazzo M, et al. Enzymatic and metabolic changes in peripheral serum after superior mesenteric artery ligation in dogs. Ital J Surg Sci 1983;13:269-73.

16. Graeber GM, Cafferty PJ, Wolf RE, Harmon JW. An analysis of creatine phosphokinase in the mucosa and the muscularis of the gastrointestinal tract. J Surg Res 1984;37:376-82.

17. Graeber GM, Wolf RE, Harmon JW. Serum creatine kinase and alkaline phosphatase in experimental small bowel infarction. J Surg Res 1984;37:25-32.

18. Aldana JP, Marcovich R, Singhal P, Reddy K, Morgenstern $\mathrm{N}$, El-Hakim A, et al. Immune response to laparoscopic bowel injury. J Endourol 2003;17:317-22.

19. Lammers KM, Innocenti G, Venturi A, Rizzello F, Helwig $\mathrm{U}$, Bianchi GP, et al. The effect of transient intestinal ischemia on inflammatory parameters. Int J Colorectal Dis 2003;18:78-85.

20. Jakobsen BW, Pedersen J, Egeberg BB. Postoperative lymphocytopenia and leucocytosis after epidural and general anaesthesia. Acta Anaesthesiol Scand 1986;30:668-71.

21. Nanji AA, Freeman JB, Nair G. Postoperative leukocytosis in morbidly obese patients: relationship to serum cholesterol. Am J Hematol 1985;20:417-8.

22. Acosta S, Nilsson TK, Björck M. Preliminary study of $\mathrm{D}$-dimer as a possible marker of acute bowel ischaemia. $\mathrm{Br}$ J Surg 2001;88:385-8. 